\title{
Influence of grass species and stage of maturity at ensiling on intake and partial digestibility by sheep
}

\author{
W.A. van Niekerk ${ }^{\#}$, Abubeker Hassen and F.M. Bechaz \\ Centre for Nutrition, Department of Animal and Wildlife Sciences, University of Pretoria, South Africa
}

\begin{abstract}
The aim of this study was to compare intake and partial digestibility of organic matter (OM) and nitrogen $(\mathrm{N})$ of two ensiled tropical grass species, $P$. maximum and $D$. eriantha, made either at the boot or full bloom stage of growth. Intake and digestibility were determined by the double marker technique where $\mathrm{Yb}$ and $\mathrm{Cr}$ were infused continuously into the rumen with a peristaltic pump. Except for OM disappearance in the digestive tract, neither species nor stage of harvesting had an effect on intake, digesta flow and OM disappearance within the rumen and small intestine. For $P$. maximum silage, $N$ intake $(g / d)$ was higher at the full bloom than at the boot stage. Total abomasum $N$ flow $(g / d)$, non-ammonia nitrogen (NAN) flow (g/d), NAN flow per $\mathrm{N}$ intake and NAN disappearance as $\%$ of $\mathrm{N}$ intake in the gastrointestinal tract (GIT) were higher for sheep fed on $D$. eriantha than P. maximum silage made at full bloom. In $D$. eriantha silage NAN disappearance was higher for silage at full bloom than $D$. eriantha silage at boot stage. The true $N$-digested (\%), however, did not differ significantly between the species or stage of maturity. In terms of NAN disappearance in the lower GIT it is evident that silage made from D. eriantha at the full bloom stage is superior to silage made at the boot stage, as well as to silage made from P. maximum.
\end{abstract}

Keywords: Boot stage, Digitaria eriantha, non-ammonia nitrogen, organic matter disappearance, Panicum maximum

${ }^{\#}$ Corresponding author. E-mail: willem.vanniekerk@up.ac.za

\section{Introduction}

Panicum maximum (Guinea grass) and Digitaria eriantha (Smuts finger) grass are adapted to a wide range of climatic and soil conditions (Aganga \& Tshwenyane, 2004). The silage made from these grasses could supply quality roughages during the late winter and early spring periods when natural pasture has a poor nutritive value (Tainton, 2000). The objective of this study was to compare intake and partial digestibility of organic matter $(\mathrm{OM})$ and nitrogen $(\mathrm{N})$ of two ensiled tropical grass species $(P$. maximum and D. eriantha) either at the boot or full bloom stage of growth.

\section{Materials and Methods}

Panicum maximum and D. eriantha pastures were harvested each from an area of 0.4 ha at two stages (boot and full bloom) of growth. Each of these grasses were separately wilted to a dry matter (DM) concentration of $30 \%$ and ensiled with the addition of $8 \mathrm{~kg}$ sugar/ton DM in airtight plastic bags (3.1 $\mathrm{m} \mathrm{x}$ $2.75 \mathrm{~m})$.

Four silage diets were studied in a 2 x 2 factorial experimental design. The treatments consisted of two grass species (P. maximum or D. eriantha) and two growth stages (boot or full bloom) at harvest. Four multicannulated sheep fitted with ruminal, abomasal and ileal cannulas were randomly allocated to one of the four silage diets for the partial digestibility study. The animals were fitted with faecal collection bags. The sheep were housed in individual metabolism crates and fed ad libitum. The animals had free access to a $50: 50$ dicalcium phosphate/salt lick and fresh water was available.

The double marker technique, with continuous infusion and sampling at pre-determined times, as described by Faichney (1975), was used to determine the partial digestibility of the silage. Chromium (Cr)EDTA (220 mg Cr per day) (liquid phase marker) and ytterbium (Yb)-acetate (90 mg Yb per day) (solid phase marker) were infused continuously with a peristaltic pump into the rumen for $24 \mathrm{~h}$ per day over a 
period of eight days. The exact sampling times of ruminal and abomasal fluid were: day 1 at 09:00 and 21:00; day 2 at 12:00 and 24:00; day 3 at 15:00 and 03:00; and day 4 at 18:00 and 06:00.

Ruminal and abomasal fluid were collected, thawed and the supernatants were used for determination of rumen ammonia nitrogen $\left(\mathrm{NH}_{3}-\mathrm{N}\right)$. Total faecal excretion was measured twice daily at 08:00 and 18:00 and a $10 \%$ subsample of the faeces was pooled and frozen pending analysis. Abomasal fluid samples were thawed and a portion of the sample was centrifuged to determine concentrations of $\mathrm{NH}_{3}-\mathrm{N}, \mathrm{Yb}$ and $\mathrm{Cr}$ (Morgan et al., 1976). Feed intake was estimated by recording the amount of silage offered and refused.

Dry matter, ash and N concentrations were determined according to AOAC (2000) methods and neutral detergent fibre (NDF) concentration according to Robertson \& Van Soest (1981).

All parameters were analyzed using Proc GLM of SAS (2001). The influence of grass species and growth stage was investigated and where the $F$ ratio showed significance differences $(P<0.05)$, the means were tested using Bonferroni's test according to Samuels (1989).

\section{Results and Discussion}

Table 1: Partial digestibility of organic matter by sheep fed P. maximum and $D$. eriantha silages harvested at boot and full bloom stages of growth

\begin{tabular}{|c|c|c|c|}
\hline \multirow[b]{2}{*}{ Parameters } & \multirow{2}{*}{$\begin{array}{l}\text { Stage of } \\
\text { growth at } \\
\text { harvest }\end{array}$} & \multicolumn{2}{|c|}{ Pasture species } \\
\hline & & $\begin{array}{l}\text { Panicum } \\
\text { maximum }\end{array}$ & $\begin{array}{l}\text { Digitaria } \\
\text { eriantha }\end{array}$ \\
\hline \multicolumn{4}{|l|}{ Intake } \\
\hline \multirow[t]{2}{*}{ OMI (g/d) } & Boot & $977_{1}^{\mathrm{a}}( \pm 12.4)$ & $978_{1}^{\mathrm{a}}( \pm 12.4)$ \\
\hline & Full bloom & $1086_{1}^{\mathrm{a}}( \pm 12.4)$ & $1194_{1}^{\mathrm{a}}( \pm 12.4)$ \\
\hline \multirow[t]{2}{*}{ DOMI (g/kg W' $\left.{ }^{0.75} / \mathrm{d}\right)$} & Boot & $33.2_{1}^{\mathrm{a}}( \pm 2.2)$ & $32.2_{1}^{\mathrm{a}}( \pm 2.2)$ \\
\hline & Full bloom & $33.9_{1}{ }^{\mathrm{a}}( \pm 2.2)$ & $38.9_{1}^{\mathrm{a}}( \pm 2.2)$ \\
\hline \multicolumn{4}{|l|}{ Digesta flow (L/d) } \\
\hline \multirow[t]{2}{*}{ Abomasum } & Boot & $24.3_{1}{ }^{\mathrm{a}}( \pm 2.2)$ & $19.4_{1}^{\mathrm{a}}( \pm 2.2)$ \\
\hline & Full bloom & $19.2^{\mathrm{a}}( \pm 2.2)$ & $19.1_{1}^{\mathrm{a}}( \pm 2.2)$ \\
\hline \multirow[t]{2}{*}{ Ileum } & Boot & $7.1_{1}^{\mathrm{a}}( \pm 1.2)$ & $6.7_{1}^{\mathrm{a}}( \pm 1.2)$ \\
\hline & Full bloom & $5.8_{1}^{\mathrm{a}}( \pm 1.2)$ & $5.6_{1}^{\mathrm{a}}( \pm 1.2)$ \\
\hline \multicolumn{4}{|l|}{ OM disappearance in the rumen } \\
\hline \multirow[t]{2}{*}{ Disappearance in the rumen $(\mathrm{g} / \mathrm{d})$} & Boot & $475_{1}^{\mathrm{a}}( \pm 11.6)$ & $499_{1}{ }^{\mathrm{a}}( \pm 11.6)$ \\
\hline & Full bloom & $599_{1}{ }^{\mathrm{a}}( \pm 11.6)$ & $615_{1}^{\mathrm{a}}( \pm 11.6)$ \\
\hline \multirow{2}{*}{ Disappearance as \% of OMI } & Boot & $48_{1}^{a^{a}}( \pm 3.2)$ & $51_{1}^{\mathrm{a}}( \pm 3.2)$ \\
\hline & Full bloom & $55_{1}^{\mathrm{a}}( \pm 3.2)$ & $51_{1}^{\mathrm{a}}( \pm 3.2)$ \\
\hline \multirow{2}{*}{ OM disappearance in the small intestine } & Boot & $107_{1}^{\mathrm{a}}( \pm 9.1)$ & $107_{1}^{\mathrm{a}}( \pm 9.1)$ \\
\hline & Full bloom & $158_{1}^{\mathrm{a}}( \pm 9.1)$ & $204_{1}^{\mathrm{a}}( \pm 9.1)$ \\
\hline \multirow{2}{*}{$\begin{array}{l}\text { OM disappearance in small intestine as \% of } \\
\text { OMI }\end{array}$} & Boot & $11_{1}^{\mathrm{a}}( \pm 2.8)$ & $11_{1}^{\mathrm{a}}( \pm 2.8)$ \\
\hline & Full bloom & $15_{1}^{\mathrm{a}}( \pm 2.8)$ & $17_{1}^{\mathrm{a}}( \pm 2.8)$ \\
\hline \multirow{2}{*}{ OM disappearance in GIT as \% of OMI } & Boot & $74_{1}^{\mathrm{a}}( \pm 2.4)$ & $74_{1}^{\mathrm{a}}( \pm 2.4)$ \\
\hline & Full bloom & $72_{1}^{\mathrm{a}}( \pm 2.4)$ & $75_{1}{ }^{\mathrm{a}}( \pm 2.4)$ \\
\hline
\end{tabular}

Means within columns (a,b) and rows $(1,2)$ with different superscripts differ significantly at $\mathrm{P}<0.05$.

Grass species had no significant effect on intake, digesta flow and OM disappearance, both in the abomasum and ileum of sheep fed on the silages (Table 1). Generally the level of digestible OM intake per $\mathrm{kg} \mathrm{W}^{0.75}$ ranged from 32.2 to $38.9 \mathrm{~g} / \mathrm{kg} \mathrm{W}^{0.75} / \mathrm{d}$ and, according to Engels (1972), this is sufficient to meet the maintenance requirement of grazing sheep. The digesta flow both in the abomasum and ileum as well as OM 
disappearance in the rumen and GIT recorded in our study is within the range reported by Relling et al. (2001) while the OM disappearance values in the small intestine were generally low compared to values reported for $P$. maximum pasture during summer.

The partial digestibility of $\mathrm{N}$ of the two grass silages is presented in Table 2 . The total $\mathrm{N}$ intake $(\mathrm{g} / \mathrm{d})$ of the sheep was not significantly different $(\mathrm{P}>0.05)$ among the two grass species. However, the total $\mathrm{N}$ flow (g/d), non-ammonia nitrogen (NAN) flow (g/d) and NAN flow per N intake in the abomasum for $D$. eriantha were higher than $P$. maximum silage when compared at the full bloom stage. The high level of disappearance of NAN for $D$. eriantha is an indication that more amino acids (of microbial protein origin) were available

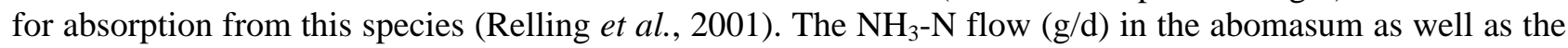
total N-flow (g/d) and NAN flow (g/d) recorded in the ileum did not differ among the two grass species. At boot stage $D$. eriantha silage had a higher $\mathrm{NH}_{3}-\mathrm{N}$ flow (g/d) in the ileum than $P$. maximum silage, while the two grass silages didn't differ when compared at the full bloom stage.

Table 2: Partial digestibility of nitrogen in sheep fed P. maximum and D. eriantha at boot and full bloom stage of growth

\begin{tabular}{|c|c|c|c|}
\hline \multirow[b]{2}{*}{ Parameters } & \multirow[b]{2}{*}{$\begin{array}{l}\text { Stage of growth at } \\
\text { harvest }\end{array}$} & \multicolumn{2}{|c|}{ Pasture species } \\
\hline & & $\begin{array}{l}\text { Panicum } \\
\text { maximum }\end{array}$ & $\begin{array}{l}\text { Digitaria } \\
\text { eriantha }\end{array}$ \\
\hline $\mathrm{N}$ intake $(\mathrm{g} / \mathrm{d})$ & $\begin{array}{l}\text { Boot } \\
\text { Full bloom }\end{array}$ & $\begin{array}{l}20.0_{1}^{\mathrm{b}}( \pm 2.0) \\
28.1_{1}^{\mathrm{a}}( \pm 2.0)\end{array}$ & $\begin{array}{l}25.5_{1}^{\mathrm{a}}( \pm 2.0) \\
27.4_{1}^{\mathrm{a}}( \pm 2.0)\end{array}$ \\
\hline \multicolumn{4}{|l|}{ Abomasum } \\
\hline Total N-flow (g/d) & $\begin{array}{l}\text { Boot } \\
\text { Full bloom }\end{array}$ & $\begin{array}{l}19.5_{1}{ }^{\mathrm{a}}( \pm 2.2) \\
20.5_{2}^{\mathrm{a}}( \pm 2.2)\end{array}$ & $\begin{array}{l}21.0_{1}^{\mathrm{a}}( \pm 2.2) \\
27.5_{1}^{\mathrm{a}}( \pm 2.2)\end{array}$ \\
\hline $\mathrm{NH}_{3}-\mathrm{N}$ flow (g/d) & $\begin{array}{l}\text { Boot } \\
\text { Full bloom }\end{array}$ & $\begin{array}{l}2.1_{1}^{\mathrm{a}}( \pm 0.8) \\
1.9_{1}^{\mathrm{a}}( \pm 0.8)\end{array}$ & $\begin{array}{l}2.3_{1}^{\mathrm{a}}( \pm 0.8) \\
1.9_{1}^{\mathrm{a}}( \pm 0.8)\end{array}$ \\
\hline NAN flow (g/d) & $\begin{array}{l}\text { Boot } \\
\text { Full bloom }\end{array}$ & $\begin{array}{l}17.4_{1}^{\mathrm{a}}( \pm 2.2) \\
18.6_{2}{ }^{\mathrm{a}}( \pm 2.2)\end{array}$ & $\begin{array}{l}18.7_{1}^{\mathrm{a}}( \pm 2.2) \\
25.6_{1}^{\mathrm{a}}( \pm 2.2)\end{array}$ \\
\hline NAN flow/N-intake & $\begin{array}{l}\text { Boot } \\
\text { Full bloom }\end{array}$ & $\begin{array}{l}0.87_{1}^{\mathrm{a}}( \pm 0.04) \\
0.66_{2}{ }^{\mathrm{a}}( \pm 0.04)\end{array}$ & $\begin{array}{l}0.74_{1}{ }^{\mathrm{a}}( \pm 0.04) \\
0.95_{1}{ }^{\mathrm{a}}( \pm 0.04)\end{array}$ \\
\hline \multicolumn{4}{|l|}{ Ileum } \\
\hline Total N-flow (g/d) & $\begin{array}{l}\text { Boot } \\
\text { Full bloom }\end{array}$ & $\begin{array}{l}8.5_{1}^{\mathrm{a}}( \pm 1.5) \\
7.7_{1}^{\mathrm{a}}( \pm 1.5)\end{array}$ & $\begin{array}{l}8.9_{1}^{\mathrm{a}}( \pm 1.5) \\
10.2_{1}^{\mathrm{a}}( \pm 1.5)\end{array}$ \\
\hline $\mathrm{NH}_{3}-\mathrm{N}$ flow $(\mathrm{g} / \mathrm{d})$ & $\begin{array}{l}\text { Boot } \\
\text { Full bloom }\end{array}$ & $\begin{array}{l}0.11_{2}^{\mathrm{a}}( \pm 0.20) \\
0.10_{1}^{\mathrm{a}}( \pm 0.20)\end{array}$ & $\begin{array}{l}0.22_{1}^{\mathrm{a}}( \pm 0.20) \\
0.10_{1}^{\mathrm{b}}( \pm 0.20)\end{array}$ \\
\hline NAN flow (g/d) & $\begin{array}{l}\text { Boot } \\
\text { Full bloom }\end{array}$ & $\begin{array}{l}8.4_{1}^{\mathrm{a}}( \pm 1.4) \\
7.6_{1}^{\mathrm{a}}( \pm 1.4)\end{array}$ & $\begin{array}{l}8.7_{1}^{\mathrm{a}}( \pm 1.4) \\
10.1_{1}^{\mathrm{a}}( \pm 1.4)\end{array}$ \\
\hline NAN disappearance (\% of $N$ intake) & $\begin{array}{l}\text { Boot } \\
\text { Full bloom }\end{array}$ & $\begin{array}{l}45_{1}^{\mathrm{b}}( \pm 3.7) \\
39_{2}^{\mathrm{a}}( \pm 3.7)\end{array}$ & $\begin{array}{l}40_{1}{ }^{\mathrm{b}}( \pm 3.7) \\
58_{1}^{\mathrm{a}}( \pm 3.7)\end{array}$ \\
\hline True N-digested (\%) & $\begin{array}{l}\text { Boot } \\
\text { Full bloom }\end{array}$ & $\begin{array}{l}88_{1}{ }^{\mathrm{a}}( \pm 1.6) \\
89_{1}^{\mathrm{a}}( \pm 1.6)\end{array}$ & $\begin{array}{l}86_{1}^{\mathrm{a}}( \pm 1.6) \\
86_{1}^{\mathrm{a}}( \pm 1.6)\end{array}$ \\
\hline
\end{tabular}

Means within columns (a,b) and rows $(1,2)$ with different superscripts differ significantly at $\mathrm{P}<0.05$.

At full bloom stage, $D$. eriantha had a higher GIT NAN disappearance (as $\%$ of $\mathrm{N}$ intake) than $P$. maximum silage, while the two grass silages didn't differ when compared at boot stage. Generally the two grass silages did not differ in terms of true $\mathrm{N}$ digested (\%) in the GIT.

Growth stage had no effect on intake, digestion and OM disappearance in the abomasum and ileum (Table 1). In contrast, Relling et al. (2001) reported a decrease in intake, abomasal digesta flow and OM 
disappearance in the small intestine with increasing maturity for P. maximum pasture harvested during the summer period. However, these parameters were not significantly different for the same species for autumn and winter harvest.

For $P$. maximum, higher $\mathrm{N}$ intake was recorded in sheep fed full bloom compared to boot stage silage (Table 2). This was due to a higher $\mathrm{N}$ concentration of $P$. maximum silage that was recorded at full bloom than boot stage (Hassen et al., 2009). In D. eriantha silage, however, growth stage had no significant effect on N intake. Generally growth stage had no effect on the total $\mathrm{N}$ flow (g/d) and NAN flow (g/d) in both the abomasum and ileum. In contrast, Relling et al. (2001) found a lower abomasal $\mathrm{N}$ flow with increasing stage of maturity mainly associated to $\mathrm{N}$, which is present in the fibre component. However, for $D$. eriantha the ileum $\mathrm{NH}_{3}-\mathrm{N}$ flow (g/d) was higher in boot stage than full bloom stage silage. In contrast the $\mathrm{NH}_{3}-\mathrm{N}$ flow in the abomasum generally was not affected by the growth stage. Likewise for $P$. maximum silage growth stage had no effect on ileal $\mathrm{NH}_{3}-\mathrm{N}$ flow.

In $D$. eriantha, full bloom stage silage had higher GIT NAN disappearance (as \% of $N$ intake) than boot stage silage. In contrast, for $P$. maximum silage growth stage had no effect on GIT NAN disappearance. Growth stage had also no effect on true N digested (\%) in the GIT by sheep fed the two grass silages (Table 2). In contrast, Relling et al. (2001) found lower total tract $\mathrm{N}$ disappearance with increasing stage of maturity for $P$. maximum pasture during summer and autumn, but not during the winter period.

\section{Conclusions}

No differences occurred in terms of OMI and disappearance between P. maximum and D. eriantha silage, ensilaged either at the boot or full bloom stage. The N and NAN flow as well as NAN disappearance favoured the full bloom ensiled stage of $D$. eriantha silage, resulting in a higher nutritive value for lambs compared to $P$. maximum silage.

\section{References}

Aganga, A.A. \& Tshwenyane, S., 2004. Potentials of Guinea grass (Panicum maximum) as forage crop in livestock production. Pak. J. Nutr. 3, 1-4.

AOAC, 2000. Official methods of analysis (17th ed.). Association of Official Analytical Chemists, Inc., Arlington, Virginia, USA.

Engels, E.A.N., 1972. A study of the nutritive value of natural and sown pastures in the central Orange Free State with special reference to the energy requirements of sheep. $\mathrm{PhD}$ Thesis, University of Stellenbosch, South Africa.

Faichney, G.J., 1975. The use of markers to partition digestion within the gastro-intestinal tract of ruminants. In: Proc. fourth Int. Symp. Ruminant Physiology. Eds McDonald, I.W. \& Warner, A.C.T., University of New England Publ. Unit, Armidale, N.S.W., Australia. pp. 277-291.

Hassen, A., Van Niekerk, W.A. \& Bechaz, F.M., 2009. Silage fermentation attributes and certain rumen parameters of sheep fed two grass silages harvested at different stages of maturity. S. Afr. J. Anim. Sci. 39 (Suppl. 1), 229-233.

Morgan, P.J.K., Pienaar, J.P. \& Clark, R.A., 1976. Animal based methods of determining herbage intake and quality under grazing conditions. Proc. Grassl. Soc. S. Afr. 11, 73-76.

Relling, E.A., Van Niekerk, W.A., Coertze, R.J. \& Rethman, N.F.G., 2001. An evaluation of Panicum maximum cv Gatton: 3. The partial digestion by sheep of organic matter, nitrogen and neutral detergent fibre of herbage at three stages of maturity during summer, autumn and winter. S. Afr. J. Anim. Sci. 31, 93-99.

Robertson, J.B. \& Van Soest, P.J., 1981. The detergent system of analysis and its application to human foods. In: The Analysis of Dietary Fiber in Food. Eds James, W.P.T. \& Theander, O., Marcel Dekker, New York. pp. 123-158.

Samuels, M.L., 1989. Statistics for Life Sciences. Collier Macmillan Publishers, London, UK.

SAS, 2001. Institute Inc., SAS/STAT User's Guide, Version 6, Fourth Edition, Volume 1, Cary, NC: SAS Institute INC. p 943.

Tainton, N., 2000. Pasture Management in South Africa. University of Natal Press, Pietermaritzburg, South Africa. 